\title{
ІНТЕЛЕКТУАЛЬНА КОМУНІКАЦІЯ ЯК УМОВА ЕФЕКТИВНОСТІ СОЦІАЛЬНОГО ПІЗНАННЯ
}

\begin{abstract}
О.П. Панафідіна
Соціально-організуюча, або практично-перетворювальна, функція науки визнається самими науковцями однією із провідних. Однак її реалізація вимагає відповідального ставлення як до процесу впровадження інновацій, так і до їх теоретичного обгрунтування. Ефективність соціального пізнання передбачає його результативність, тобто можливість досягнення максимально бажаних результатів. А від ефективності соціального пізнання, в свою чергу, залежить ефективність перетворень у суспільній сфері. Відтак високий рівень методологічної, а також етичної культури $є$ необхідною передумовою діяльності вчених на сучасному етапі еволюції науки. Спекуляції на зразок «варіації на тему. ..» можуть мати трагічні наслідки при спробі їх практичної реалізації, що зумовлює потребу у розробці наукового методу, заснованого на принципі інтерактивності. Колективний характер інтелектуальної діяльності мінімізує суб'єктивізм, перегини при дослідженні явищ навколишньої дійсності, усвідомлення чого є особливо актуальним за умови тісного зв'язку теорії і практики. Якщо для природничих наук такий підхід став нормою, то для суспільних - його важливість на разі потребує, на наш погляд, свого доведення.

В останній третині XX століття виникла нова дисципліна - етика науки, яка покликана вивчати моральні засади наукової діяльності, сукупність ціннісних принципів, прийнятих у науковому співтоваристві, i яка концентрує в собі соціальний і гуманістичний аспекти науки $[6$, c. 448]. Однак під наукою тут розуміються перш за все дослідження в технічній та біологічній сферах. Натомість, на нашу думку, міра відповідальності в суспільнознавчій сфері аж ніяк не менша, а можливо
\end{abstract}

Актуальні проблеми духовності

(Відп. ред.: Я.В. Шрамко)

Кривий Ріг (2007), 162-175 
й на порядок вища, ніж у природознавстві. Адже досвід ХХ століття засвідчив, що внаслідок крупномасштабних соціальних експериментів на «науковій» основі реальністю, в супереч очікуванням, стає трагедія мільйонів людей. Переосмислення зазначених подій здійснюється представниками різних наукових напрямків (істориками, соціологами, політологами, філософами), виходячи з різних методологічних засад. Але нам хотілося б звернути увагу на проблему «науковості» тих положень, що були покладені в основу соціальних перетворень, які відбувалися під гаслами на перший погляд цілком гуманними.

Характеризуючи стан дослідження означеної проблеми, виділимо такі аспекти її вирішення:

1) проблема наукового методу в суспільствознавстві (наукова критика versus соціальний критицизм; ймовірна єдність методу для природничих та суспільних наук);

2) проблема відповідальності за результати дослідження (сутність постнекласичної раціональності; співвідношення знання з ціннісно-цільовими структурами діяльності; зміна світоглядних орієнтацій техногенної цивілізації);

3) реальна практика в сфері суспільних наук (формальне визнання плюралізму, а в науковій та педагогічній практиці - опора здебільшого на принцип методологічного монізму).

Серед публікацій, значимих в руслі нашої теми, слід назвати роботи А. Гжегорчика [2] та Г.П. Щедровицького [24], в яких розглянуто зміст процесу духовної комунікації, охарактеризовано інтелектуальну діяльність як колективну за своєю природою. Цікаві ідеї стосовно перегляду марксистської методології містяться в працях Ю. Іщенка [5] та T.I. Ойзермана [14], [15]. А міркування Л.Б. Баженова [1] й А.Ф. Овчиннікова [13] дають уявлення про можливість руйнування «інтелектуальних каркасів» в сфері суспільствознавчих досліджень.

Завданням даних розвідок є визначення ролі комунікації (як діалогу, інтеракції) у підвищенні ефективності пізнання у колі суспільствознавців при націлюванні на подальшу реалізацію їхніх поглядів та результатів теоретичних напрацювань. Здійснити його ми намагатимемося в ході систематизації сучасних уявлень про дійсно науковий підхід до вивчення суспільних явищ, а також на прикладі оцінки дієвості в даному контексті марксистської методології.

Говорячи про інтелектуальну комунікацію, ми слідуємо за Карлом Раймондом Поппером (1902-1994), який визначає її як співпрацю, досягнення компромісу та наведення інтелектуальних мостів між різними соціально детермінованими системами припущень («тотальни- 
ми ідеологіями») $[17, \text { с. 246-247 }]^{1}$. Відтак інтелектуальна комунікація передбачає взаємодію, зв'язок між науковцями, які працюють над конкретною проблемою, виходячи з власної спеціалізації, належності до тієї чи іншої філософської школи, особистого досвіду та світоглядних уявлень.

Як відомо, взаємодія між ідеями, теоріями, людьми та їх об'єднаннями і т.ін. може здійснюватися у двох формах: у формі співробітництва та у формі суперництва. Взаємодія як співробітництво й передбачає процес комунікації (від лат. communicare - радитися з кимнебудь), обміну думками, спільного вирішення актуальних проблем, відмову від авторитарного стилю у спілкуванні та управлінні. Це здорова альтернатива суперництву, яке іноді зводиться до самоцілі (тобто суперництво заради перемоги будь-якою ціною). Натомість комунікація передбачає орієнтацію не на егоцентричне бажання досягти успіху, а на досягнення розуміння та ефективності в окремому роді діяльності, в т. ч. науковій. Так, А. Гжегорчик зазначає, що обмін думками, який збагачує процес пізнання, відбувається в ході інтелектуального діалогу. Останній він визначає як інтеракцію, тобто таку послідовність дій, в якій беруть участь щонайменше два учасника і після певної поведінки однієї сторони наступає поведінка іншої сторони у вигляді відповіді. Подібна інтеракція може тривати невизначено довгий час $[2$, с.58], однак $\dddot{11}$ результативність зрештою є безсумнівною.

На думку К. Поппера, у взаєминах між вченими-суспільствознавцями домінує здебільшого суперництво, оскільки соціальні науки на разі не виробили власного дієвого теоретичного інструментарію, націленого на критичне сприйняття і оцінку власних мислених конструкцій, як це сталося в фізиці з часів Галілео Галілея, а в біології-з часів Луї Пастера. «В соціальних науках, мабуть, - пише Поппер, - свій Галілей ще не з'явився» [16, № 8, с. 52]. Критика тут спрямована лише на позицію опонента. Впевненість у непогрішимості власної точки зору або вчення, відсутність сумніву у ймовірній наявності помилок не можуть бути основою справжнього наукового методу, наукового підходу до вивчення суспільних явищ. Догматичність мислення і наука - peчі несумісні. Наука - це постійний пошук творчого дослідника, а не діяльність за шаблонами, оперування готовими формулами, які вважаються за будь-яких умов істинними. Інакше мова йде про релігійне

\footnotetext{
${ }^{1}$ Хоча в сучасній комунікативній філософії під комунікацією розуміють інформаційний вплив її суб'єкта на об'єкт, що переслідує цілі, визначені суб'єктом. А те, що Поппер визначає як комунікацію, позначається як «спілкування» [10, с. 40].
} 
вірування, а не наукове вчення ${ }^{2}$.

Метод, який K.Поппер називає справді науковим і пропонує застосовувати при дослідженні суспільних явищ (як, до речі, і природничих), - метод наукової критики (або метод спроб і помилок). Його сутність полягає у тому, що науковцями висуваються достатньо численні й оригінальні гіпотези, а також певне їх вирішення - теорії, які ретельно перевіряються. Якщо перевірка засвідчила хибність теорії, то остання елімінується. В результаті залишається найбільш ймовірна теорія. Теоретична конструкція, яка не спростовується жодною уявною подією, на думку К. Поппера, є ненауковою, адже «найхарактерніша риса наукового методу як раз і полягає у тому, щоб вчені не пошкодують сил для критики та перевірки теорії, що обговорюється» [18, с. 119]. Метод спроб і помилок цілком відповідає його позиції критичного раціоналізму. Пояснюючи зміст власного підходу, К. Поппер акцентує увагу на тому, що раціоналізм - це налаштованість вислуховувати критичні зауваження і вчитися на досвіді, тобто це позиція, яка передбачає, що «я можу помилятися, і ти можеш помилятися, але спільними зусиллями ми можемо поступово наближатися до істини» $[17$, с.260]. Отже, змістом раціоналістичного підходу є повага дослідника до розуму, до логічних доведень та до думок колег.

Прикладом справді наукової теорії, на думку К. Поппера, може слугувати релятивістська програма Альберта Ейнштейна. На перших порах свого існування спеціальна теорія відносності не передбачала нічого нового у порівнянні з суперницями (наприклад, програмами Лоренца і Пуанкаре) і навіть протягом 1905-1906 рр. суперечила даним експериментів Бухерера щодо відхилення катодних променів в магнітних полях. Але, зауважує Р.М.Нугаєв, «теорія А.Ейнштейна 3 самого початку перевершувала суперниць перш за все в тому, що була основою для широкого діалогу не тільки теоретичних онтологій, але й емпіричних і теоретичних дослідницьких практик та цінностей різних фундаментальних фізичних теорій, зокрема, ньютонівської механіки, максвелівської електродинаміки, термодинаміки, больцманівської статистичної механіки» [12, с. 121-122]. Отже, програма Ейнштейна пере-

\footnotetext{
${ }^{2}$ На наш погляд, зазначена позиція Поппера має сенс з огляду на те, що на думку багатьох дослідників у сучасній науці формується новий тип раціональності - постнекласичний, який характеризується, зокрема, зміною об'єкта дослідження. Науковці зосереджуються на вивченні складних систем, які історично розвиваються. А це, у свою чергу, означає необхідність враховувати велику кількість нюансів, які на перший погляд (або й взагалі) можуть здатися несуттєвими, але у далекій перспективі мати неабияке значення. Таким чином, актуалізується колективний принцип наукової діяльності.
} 
могла у конкурентній боротьбі не в останню чергу через їі здатність бути основою для справжньої комунікації між представниками провідних парадигм старої фізики, які до Ейнштейна знаходилися у стані значної психологічної, інституціональної та культурної ізоляції.

Таким чином, науковий метод має суспільний або публічний характер. Його завдання - досягнення наукової об'єктивності, що відбувається в результаті «дружньо ворожої співпраці багатьох вчених». Наукова об'єктивність, переконаний К. Поппер, не може бути результатом спроб окремого вченого стати «об'єктивним». Лише інтерсуб'єктивність наукового методу та конструктивна критика будь-якої теоpiї, навіть авторитетів, з боку інших дослідників забезпечать індивідуальну неупередженість вченого [17, с. 251-253], але в жодному разі не навпаки. Зрештою критика є головною рушійною силою будь-якого інтелектуального розвитку, оскільки вона, по суті, зводиться до виявлення протиріч (або в межах самої теорії, або між теорією та певними судженнями про факти) та їх подальшого усунення, що можна вважати раціональним підгрунтям трансформації теорії [18, с.121], яка прагне отримати статус дійсно наукової. Адже теорія, котра містить у собі протиріччя, абсолютно непотрібна, оскільки «з неї випливає все що завгодно, а отже не випливає нічого» [18, с. 124].

Зазначені вимоги до наукового методу (вільний критицизм і публічність) задовольняються в природничих науках, але поки що не стали у повній мірі надбанням соціальних наук, що ставить під сумнів їх ефективність. К. Поппер вважає, що соціальні науки є справжніми «тотальними ідеологіями», які не мають чітко визначених меж ймовірного застосування. Вони легко знаходять факти свого підтвердження, а протилежні ідеї та теорії оголошують недостатньо надійними, мало зважаючи на можливість майбутнього свого спростування досвідом. Така ситуація має місце, на думку К. Поппера, в астрології, психоаналізі Фрейда, релігійних вченнях, гегельянстві, неопозитивізмі, марксизмі, соціології знання [11, с. 100], [17, с. 249]. «Тотальні ідеологї̈»- це соціально-детерміновані системи безумовно істинних і самоочевидних припущень, переконань і теорій. Мислитель, який живе в іншому середовищі, також спирається на систему безумовних, як йому здається, припущень, але вже геть відмінну від попередньої. Їхні позиції можуть кардинально відрізнятися одна від іншої, тим самим не передбачаючи наявності жодного «інтелектуального моста». У такому випадку, на думку К.Поппера, мова буде йти лише про суперництво, в основі якого лежить або ірраціоналістичний, або псевдораціоналістичний (інтелектуальний інтуїціонізм Платона) підхід. Тут немає місця для 
конструктивної співпраці, здорового компромісу тощо. Одним із найвиразніших прикладів «тотальної ідеології», з точки зору Поппера, є марксизм.

Карл Маркс (1818-1883) - розробник класової теорії суспільства, котра грунтується на ідеї класової боротьби між експлуататорами $\mathrm{i}$ пригнобленими. Інтереси кожного з класів детермінують їхні погляди на різні сфери суспільного життя, зокрема наукову. Відтак усі люди мають бути поділені на друзів і ворогів, панів і підлеглих, претендуючих на безумовну істинність уявлень і тих, хто помиляється через належність до реакційних класів. Лише інтелігенція, котра у відповідності до принципу партійності виражатиме інтереси пролетаріату, досягне справді наукової об'єктивності, оскільки не матиме власної «тотальної ідеології». Остання теза розроблялася вже не Марксом, а його послідовником В.І. Леніним, однак, на наш погляд, вона цілком відповідає позиції самого Маркса і до того ж значно вплинула на становище наук про суспільство, особливо вітчизняних. Тут доречно було б згадати сучасні дискусії стосовно необхідності розрізняти автентичне вчення самого К. Маркса та те, що сформувалося в ході розвитку його ідей численними послідовниками і отримало в подальшому назву марксизм. Так, Т. Рокмор говорить про нагальну потребу у «відкритті Маркса після марксизму» [19]. Однак не слід забувати й про те, що марксизм почав формуватися ще за життя основоположника i, як буде показано далі, саме вчення Маркса включало суперечливі судження, висловлені в різні періоди його творчої біографії. Відтак було створено прецедент можливості різних тлумачень поглядів оригінального мислителя. Але орієнтацію на практичну реалізацію «поглядів Маркса» приймали усі його послідовники, вірячи в те, що саме вони вірно зрозуміли настанови вчителя.

У зв'язку з цим слід зазначити, що теорія наукового соціалізму від самого початку претендувала на статус програми практичного перетворення дійсності. Ї̈̈ завданням було знайти виправдання і обгрунтувати необхідність революційної боротьби найманих робітників (пролетаріату) за свої права. Тобто наука не була для Маркса самоціллю, а лише засобом обгрунтування його віри в те, що комунізм змінить світ на краще. Так, О.Б.Гофман зазначає, що не наука привела Маркса до ідеалу комунізму, а навпаки, він намагався знайти наукове обгрунтування уже вкоріненому у його свідомості комуністичному ідеалу. Зокрема, «Маніфест Комуністичної партії», в якому виражений комуністичний «символ віри», був написаний ще у грудні 1847-січні 1848 pp., тобто задовго до головних наукових робіт Маркса ( Німецька іде- 
ологія», «Критика політичної економіі» та ін.), коли він ще тільки починав вивчати суспільство, якому пророкував загибель [3, с. 100].

Однак К. Маркс завжди наголошував, що він дотримується ідеалів науковості (об'єктивність, неупередженість, антидогматичність і т. ін.) і позиціонував себе як мислителя, для котрого істина понад усе. У Маркса, дійсно, можна знайти багато місць, де він говорить про колективно-суспільне виробництво знання, суспільну форму пізнання, спілкування як практичну форму трансляції знання тощо. Практику він розглядав не тільки як критерій істинності знання, але й як їх основу, як підгрунтя наукових теорій. Більше того, надії на створення таких вчень, які втілювали б «абсолютну істину в останній інстанції, проголошувалися марними [7, с.48-49]. Але дані ідеї не є тотожними тому, що К.Поппер називав інтерсуб'єктивністю і суспільним характером наукового методу. Пояснюючи дану тезу, Поппер зазначає, що «антидогматична настанова Маркса реалізується тільки в теорії, а не в практиці ортодоксального марксизму, діалектика ж використовується марксистами ... головним чином в апологетичних цілях - для захисту марксизму від критики» [18, с. 136], а не для перегляду власної теорії та усунення з неї протиріч на основі діалогу з представниками альтернативних позицій. Отже, Маркс розробляв теорію наукового соціалізму як систему тверджень, підданих раціональному контролю на підставі критеріїв істинності й доказовості. А матеріалістично переосмислена гегелівська діалектика вважалася універсальним методом пізнання й пояснення соціальної реальності. Причому під матеріалістичною діалектикою розумілася «загальна теорія руху, зміни, розвитку, що узагальнює спеціальні теорії руху, зміни, розвитку, створені в біології, геології, астрофізиці, соціології і ряді інших наук» [15, с.1415]. Український філософ Ю.А. Іщенко стверджує, що реалізація такої позиції обернулася на теоретичне насилля: ствердження своєї і тільки своєї істини, адже вона одна. Тому для багатьох творів К. Маркса характерний насильницький, авторитарний і нетерпимий стиль мислення, зорієнтований наукою класичного типу. Він пов'язаний з установкою дати об'єктивну картину світу в її істинності [5, с. 61-63]. Дану позицію підтримує і Поппер, який, вказуючи на безсумнівні позитивні сторони діалектики (наприклад, визнання наявності раціонального зерна і в тезі, і в антитезі), водночас застерігає від їі ідеалізації та універсалізації і зазначає, що «діалектичний опис розвитку науки не завжди можна застосовувати без насилля над фактами» [18, с. 136], враховуючи «туманність манери мовлення, характерної для діалектиків» та їх позицію з приводу місця протиріч у побудові наукових теорій. Отже, в 
марксизмі передбачалося, що «на статус дійсно істинної вправі претендувати тільки та теорія, котра завдяки своїй внутрішній логіці сама спроможна безперервно якісно розвиватися шляхом вічного процесу оволодіння істиною» $[7$, с.48], тобто при застосуванні методу матеріалістичної діалектики. Відтак нетерпимість до істинного результату пізнання з боку індивіда, наукового співтовариства, соціальної групи сприймалася так само нетерпимо. У взаємодії з науковими опонентами етика політичного революціонера нерідко отримувала у К. Маркса (та особливо його послідовників) верх над етикою вченого [3, с. 127].

Така позиція $є$ доволі зручною при побудові певних теоретичних конструкцій за умови достатньо високої обізнаності і неабиякої ерудиції автора, яким, безумовно, був К. Маркс. Адже доволі легко «перемогти» протилежні погляди, оголосивши їх хибними лише з тієї причини, що вони належать до проявів т. зв. буржуазної філософської думки. Американський професор Том Рокмор стверджує, що дана стратегія не була відкриттям марксизму і сягає корінням біблейських часів, наприклад ідеї апостола Павла, який вважав, що дух християнства може бути зрозумілим лише для істинного християнина; ця установка приводить до створення замкненого кола уповноважених інтерпретаторів і виключає усіх інших [19, с. 31]. Уже згадуваний філософ Ю.А. Іщенко впевнений, що в основі зазначеної позиції лежить така важлива установка мислення як підкреслення єдності знання, віри й переконання. Дана установка виступає основою етики релігійного аскета і революціонера, яким справедливо вважається К. Маркс [5, с. 64].

По суті, про це ж пише і Г.П. Щедровицький: «Уявлення про індивідуалізований характер інтелектуальних процесів $є$ забобоном в обох смислах цього слова:

1) тим, що наперед визначено в індивідуальному розсудку в якості дійсності, яка має об'єктивний статус;

2) тим, що вже більше не піддається критичному аналізу» $[24$, c. 175].

Насправді ж природа інтелекту є колективною і комунікативною. Відповідно інтелектуальна діяльність має бути груповою діяльністю, організованою в єдине ціле структурами комунікації. Основи такого висновку Г.П. Щедровицького були закладені в діяльності Московського методологічного гуртка. Учасники гуртка досліджували інтелектуальні процеси і отримали на початку 50-х - початку 70-х pp. ХХ ст. цікаві результати у даному напрямку (див. [24]).

Таким чином, відповідно до інтерперсональної (міжособистісної) теорії розуму (або наукового методу) основою раціональної діяльно- 
сті є процес аргументації, який передбачає обопільну критику тез або аргументів (а можливо і того й іншого), а також мистецтво дослухатися до критики, яка лунає ззовні. «Ми зобов'язані суспільству нашим розумом, - пише К. Поппер, - [тобто] . . к конкретним індивідам . . . i нашій інтелектуальній взаємодії з ними» [17, с. 261-162].

K. Маркс, навпаки, орієнтувався на соціальний і класовий критицизм, який обумовлювався його політичним радикалізмом. Такий підхід до наукової діяльності виводив його за межі науки взагалі. Метод полеміки, іронії, сарказму і викриття не може розцінюватися як істинно науковий на відміну від методу наукової критики, що передбачає усунення будь-яких протиріч та врахування позиції опонентів. На наш погляд, Маркс-вчений з часом став заручником практичної спрямованості свого вчення, тобто Маркса-практика, Маркса-революціонера і Маркса-публіциста. Переконаність у власній правоті виливалась у нього в явно виражену категоричність наукових висновків. А коли емпіричні факти суперечили сформульованій теорії класової боротьби або ширше - теорії наукового соціалізму, то відкидалися не самі теоpiї (оскільки вони є безумовно істинними!), а ті факти, що їй суперечать. Адже відмовитися від власних засадничих положень, ймовірно, означало для Маркса відмову від мети власного життя - перебудови суспільства на гуманістичних принципах.

Про суперечливість марксистської теорії пише, зокрема, російський філософ T.I. Ойзерман, досліджуючи внутрішньо притаманний марксизму догматизм та його догматизацію [14]. Так, засновники марксизму, стверджує він, завжди підкреслювали правильність основних положень своїх ранніх праць, наприклад «Маніфесту Комуністичної партії (далі «Маніфест»). Отже, вони протягом всього інтелектуального життя поділяли ці загальні положення, незважаючи на реальні зміни, що мали місце в організації індустріального суспільства у др. пол. XIX ст. Ойзерман, якого важко звинуватити в упередженому ставленні до класиків марксизму, у своїй статті наводить кілька прикладів на доведення цієї тези:

1. В «Маніфесті» стверджується, що виробничі сили капіталістичного суспільства вже переросли власне капіталістичні, приватновласницькі відносини. Криза капіталістичного способу виробництва інтерпретувалася раннім Марксом як криза перевиробництва. Потім, у першому томі «Капіталу» він довів, що кризи перевиробництва $€$ тимчасовим явищем економічного циклу капіталістичного виробництва, за яким має слідувати нова хвиля економічного піднесення. Тим не менше через тридцять років $\Phi$. Енгельс в роботі «Анти-Дюрінг» повні- 
стю відтворює хибне положення про кризу перевиробництва як кризу самого капіталістичного способу виробництва. I K. Маркс з цим погоджується після прочитання рукопису даної роботи $\Phi$. Енгельса.

2. Якщо в «Маніфесті» єдино можливим шляхом соціалістичної перебудови суспільства проголошується пролетарська революція, то вже у 1872 р. К. Маркс, виступаючи на мітингу в Гаазі, заявляє, що в демократично розвинених країнах, таких як Англія і США, соціалістичні перетворення можуть бути здійснені мирним шляхом. Ця ж думка висловлюється К. Марксом у листі до лідера англійської «соціал-демократичної федерації Г. Гайндмана, у передмові до англійського видання першого тому «Капіталу», написаній $\Phi$. Енгельсом у 1886 р., та в останній статті Енгельса «Вступ до роботи К. Маркса „Класова боротьба у Франції з 1848 по 1850 р.“» (1895 рік). Але у передмові до перевидання «Маніфесту» німецькою мовою у 1872 p. K. Маркс i $\Phi$. Енгельс пишуть: «Як не сильно змінилися умови за останні двадцять п'ять років, однак розвинені у цьому „Маніфесті““ загальні основні положення залишаються цілком вірними і в теперішній час» [9, с. 89]. Це ж саме формулювання слово в слово відтворюється у передмові до англійського видання «Маніфесту» 1888 року [14, с. 38-40].

У зв'язку з цим проф. Т. Рокмор пише, що «будь-який марксист, добре обізнаний з роботами Маркса, опиняється у ,шизофренічному“" становищі, оскільки йому необхідно зберегти лояльність до взаємовиключних теорій» $[19$, с. 29]. Якщо це поєднати з безапеляційною критикою своїх опонентів або інтерпретаторів, то наявний відвертий догматизм мислення самого К. Маркса, який заперечує ненасильницьку інтелектуальну комунікацію і ставить під сумнів його (мислення) науковий характер. Хоча, наприклад, К. Поппер визнає, що факт слідування $з$ двох суперечливих висловлювань будь-якого судження не доводить некорисності самої суперечливої теорії. Але в той же час зазначає, що така паліативна теорія є джерелом серйозної небезпеки обгрунтованої відмови від конструктивної критики, а отже - краху науки як такої [18, с. 125-126]. Тобто те, що К. Поппер називає reinforced dogmatism, полишає гегелівсько-марксистську діалектику статусу науковості. (Г.А. Новічкова перекладає даний термін як «залізобетонний догматизм» $[18$, с. 136$]$, а В.Н. Садовський - як «непроникний догматизм» або «захищений від будь-якої критики догматизм» [17, с. 249].)

Цікаво порівняти установку Маркса з іншим варіантом філософського дискурсу, який ілюструють російські мислителі XIX ст. Як зазначає сучасний дослідник слов'янофільства Ф. Степун, «на противагу німецькій філософії, російська думка представляє собою не цикл за- 
мкнених систем, а ланцюг ось уже ціле століття невпинних розмов, причому розмов по суті все на одну і ту ж тему» (цит. по [23, с. 106]). На нашу думку, це можна пояснити, по-перше, такою національною особливістю філософського пошуку російських, як до речі й українських, мислителів як екзистенціальна спрямованість на спілкування, на відміну від західноєвропейських, зокрема і перш за все німецьких, націлених на чітку фіксацію думок та академічний стиль їх викладення на письмі. А по-друге, тим, що ratio, раціональність і класична наука - це винаходи західної цивілізації; і чим далі на Схід, тим менш поширеною є така установка. «Чистий» раціоналізм (у Поппера - «некритичний» або «всеохоплюючий»), характерний для науки Нового часу, орієнтований на визнання істинним лише того, що може бути доведеним логічними засобами або підтверджене досвідом. Звідси і теорія соціальної детермінації нашого знання, і наявність «тотальних ідеологій», і відсутність інтелектуального базису для будь-яких дискусій. Істина одна, і той, хто нею володіє, є недосяжним для критики. Зазначену установку намагався подолати I.Кант, але вже Г.Ф.В.Гегель повернувся до абсолютизації можливостей «чистого розуму».

Своєрідним продовженням позиції Маркса в обговорюваному контексті можна вважати настанови представників Франкфуртської школи. Так, Т. Адорно і М. Хоркхаймер присвятили критиці теорії інструментального розуму свою спільну працю «Діалектика Просвітництва». Вони вважали, що «критична традиція», на яку спирається К. Поппер, насправді є «застарілою ліберальною моделлю». Колись вона була автентичною, але сьогодні думати, нібито до істини можна прийти шляхом вироблення компромісу за деяким «круглим столом» після тривалого і всебічного обговорення, $є$, на їх думку, ілюзією. Серед аргументів називають наступні: в науці діють жорсткі механізми контролю, селекції до академічних інституцій; відтак реальністю наукового світу $€$ конформізм, пристосування до пануючих поглядів, надання переваги правильності логічного виводу перед істиною. Отже, обробка індивіда ідеологією та індустрією культури унеможливлює демократичну процедуру обговорення в науковому середовищі [20, с.62].

3 огляду на це необхідно зазначити, що ми вільні обирати методологічні засади нашого дослідження, дотримуватися усталених поглядів («тотальних ідеологій») або постійно піддавати їх сумніву (в ході інтелектуальної комунікації). Так, дійсно, ми можемо залишатися на власних позиціях, які сформувалися в нас під впливом оточуючих людей, і знаходити все нові й нові факти на їх підтвердження, доводити до хрипоти у горлі свою правоту. А можемо вчинити інакше: силою 
своєї волі обрати складніший шлях, відмовитися від претензій на безумовну істинність наших положень, піддати сумніву їх достовірність i дозволити конструктивну критику наших поглядів з боку інших вчених. Вибір між цими двома альтернативами є суто моральним актом. Свідомий вибір означає критичну оцінку кожної з позицій, виділення позитивів і негативів, а також прорахування можливих наслідків, які логічно випливають з них. Проблема відповідальності особливо актуальна у царині суспільних наук, і особливо, коли їх представники претендують на практичну реалізацію власних теоретичних конструкцій. Досить небезпечними є безапеляційні судження і міркування вчених-суспільствознавців, які ігнорують реальні факти, що суперечать їхнім інтелектуальним побудовам. Призначення суспільних наук полягає у вирішенні нагальних соціальних проблем, а не конструюванні ідеальної моделі суспільного устрою. Прагнення окремих мислителів зробити людей щасливими, на думку К. Поппера, $є$ найбільш небезпечними. Адже, по суті, воно означає нав'язування іншим людям нашої системи «вищих цінностей для того, щоб вони усвідомили, що з нашої точки зору (!) має надзвичайну важливість для їх (!) щастя» [17, с. 273274]. Однак, зауважує К. Поппер, необхідно правильно розуміти наш моральний обов'язок, який полягає у тому, щоб допомагати тим, хто потребує нашої допомоги, а не робити інших щасливими, тим самим вмішуючись у їх приватне життя [17, с. 274]. Адже благородні наміри можуть при практичній реалізації мати абсолютно непередбачувані наслідки.

Таким чином, інтелектуальна комунікація як співробітництво виступає важливою умовою ефективності соціального пізнання в рамках постнекласичного типу раціональності. Ефективність передбачає дієвість, виконання поставлених завдань. А оскільки сучасний глобалізований світ вимагає інтенсивного застосування наукового знання практично в усіх сферах суспільного життя, нагальною потребою $\epsilon$ впровадження технологічного підходу до його організації, що передбачає використання дійсно наукового методу вивчення явищ соціальної дійсності та їх трансформації за певних умов. Складність об'єкту дослідження та спрямованість на вирішення практичних завдань зумовлює відповідальне ставлення до процесу формулювання його результатів. Лише інтерсуб'єктивність наукового методу може відобразити колективну суть інтелектуальної діяльності і виступити гарантом мінімізації суб'єктивізму при вивченні, а особливо оцінці й зміні, того, що має місце в реальному житті. Ми в жодному разі не заперечуємо значущості теоретичного спадку К. Маркса, але вважаємо, що дана 
теорія, як і будь-яка інша, не може претендувати на абсолютну істинність (причому мова йде як про вчення К. Маркса, так і про те, що ми сьогодні називаємо марксизмом). Відтак вона потребує перегляду своïx методологічних засад і реалізації антидогматичного підходу шляхом самокритики й саморефлексії. А це можна, на наш погляд, здійснити, приймаючи аргументи своїх опонентів, розцінюючи останніх не як ідеологічних ворогів, а як співтворців нових теорій.

\section{1 Бібліографія}

[1] Баженов Л.Б. Размышления при чтении Поппера // Вопросы философии. -2002 . - № 4. - С.159-169.

[2] Гжегориик А. Духовная коммуникация в свете идеала ненасилия // Вопросы философии. - 1992. - № 3.- С. 54-64.

[3] Гофман А.Б. Семь лекций по истории социологии. - М.: Книжный дом «Университет», 1997.

[4] Загороднюк В. Класична раціональність і постнекласична наука // Генеза. - 1995. - № 1. - С. 14-28.

[5] Іщенко Ю. Класичне і некласичне у філософії Маркса // Філософська і соціологічна думка. - 1995. - № 1-2. - С.47-67.

[6] Кохановский В.П. Основы философии науки. - Ростов н/Д: Феникс, 2005.

[7] Марксистскал философия в XIX веке. - Кн. 2. - М.: Наука, 1979.

[8] Маркс К., Энгельс Ф. Манифест Коммунистической партии // Маркс К., Энгельс Ф. Сочинения. - М.: Гос. изд-во полит. литры, 1955. - Т. 4.- С. 419-459.

[9] Маркс К., Энгельс Ф. Предисловие к переизданию «Манифеста Коммунистической партии» // Маркс К., Энгельс Ф. Сочинения. - М.: Гос. изд-во полит. лит-ры, 1955. - Т. 18.

[10] Науменко T.B. Социология массовых коммуникаций в структуре социологического знания // Социс. -2003 . - № 10. - С. 39-46.

[11] Норман Г.Э. Карл Поппер о ключевых проблемах науки XX века // Вопросы философии. - 2003. - № 5. - С.96-102. 
[12] Нугаев P.М. Смена базисных парадигм: концепция коммуникативной рациональности // Вопросы философии. - 2001. - № 1. C. 114-122.

[13] Овчинников Н.Ф. Карл Поппер - наш современник, философ XX века // Вопросы философии. - 1992. - № 8. - С. 40-48.

[14] Ойзерман Т.И. Догматизация марксизма и внутренне присущий марксизму догматизм // Вопросы философии. -2003 . - № 2.C. 31-41.

[15] Ойзерман Т.И. Опыт критического осмысления диалектического материализма // Вопросы философии. - 2000. - № 2. - С. 3-31.

[16] Поппер К. Нищета историцизма // Вопросы философии. - 1992. № 8 . - C. 49-79; № 9. - C. 22-48; № 10. - C. 29-58.

[17] Поппер К. Открытое общество и его враги. - М.: Феникс, 1992.T. 2.

[18] Попnер К. Что такое диалектика? // Вопросы философии.1995. - № 1. - С. 118-138.

[19] Рокмор Т. Об открытии Маркса после марксизма // Вопросы философии. -2000 . - № 4. - С. 28-36.

[20] Руткевич A.M. Спор о позитивизме в немецкой социологии // Вопросы философии. - 1992. - № 10. - С. 59-64.

[21] Стёпин В.С. Научное познание и ценности техногенной цивилизации // Вопросы философии. - 1989. - № 10. - С. 3-18.

[22] Фролов И.Т., Юдин Б.Г. Этика науки: Проблемы и дискуссии. М.: Политиздат, 1986.

[23] Щедрина Т.Г. Коммуникативное пространство русского философского сообщества (опыт реконструкции философского архива Густава Шпета) // Вопр. философии. - 2003. - № 8. - С. 106-118.

[24] Щедровицкий Г.П. Интеллект и коммуникация // Вопросы философии. - 2004. - №3. - С. 170-183.

[25] Энгельс Ф. Анти-Дюринг. Переворот в науке, произведённый господином Евгением Дюрингом. - М.: Политиздат, 1983. 